\title{
Religiusitas dan Kesejahteraan Subjektif pada Pasien Jantung Koroner
}

\author{
Firma Agus Tina $^{1}$ E Muhana Sofiati Utami \\ Fakultas Psikologi Universitas Gadjah Mada
}

\begin{abstract}
This research aimed to examine the relationship between religiousity and subjective well being among coronary heart patients in X hospital. It was hypothesized that there is a positive relationship between religiousity and subjective well being. There were 67 coronary heart patients in this research between the ages of 40 and 80 years old. Data analysis using Product Moment correalation technique showed $r=0,417$ with $p<$ 0,01 pointing out that there is significant positive correlation between religiousity and subjective well being. That result proved that hypothesis was accepted. Another conclusion of this study is religiousity and subjective well being of coronary heart patients are at the medium category.
\end{abstract}

Keywords : religiousity, subjective well-being, coronary heart patients.

Abstrak. Penelitian ini bertujuan untuk menguji secara empirik hubungan antara religiusitas dengan kesejahteraan subjektif pada pasien jantung koroner. Hipotesis dalam penelitian ini adalah adanya hubungan positif antara religiusitas dengan kesejahteraan subjektif. Subjek dalam penelitian ini berjumlah 67 pasien jantung koroner pada Rumah Sakit X dengan rentang usia antara $40-80$ tahun. Analisis data dengan menggunakan teknik korelasi Product Moment menghasilkan $\mathrm{r}=0,417$ dengan $\mathrm{p}<0,01$ yang menunjukkan adanya hubungan positif yang signifikan antara religiusitas dengan kesejahteraan subjektif. Kesimpulan penelitian ini menunjukkan bahwa semakin tinggi religiusitas individu, maka semakin tinggi pula kesejahteraan subjektif yang dirasakan oleh individu dan sebaliknya semakin rendah religiusitas individu maka semakin rendah pula kesejahteraan subjektif yang dirasakan. Kesimpulan lain dari penelitian ini adalah religiusitas pasien jantung koroner di Rumah Sakit X berada pada kategori sedang, begitu juga kesejahteraan subjektif pasien jantung koroner dalam penelitian ini termasuk dalam kategori sedang.

Kata kunci : religiusitas, kesejahteraan subjektif, pasien jantung koroner.

Penyakit jantung dan pembuluh darah akhir-akhir ini menjadi salah satu penyakit nomor satu di dunia yang menyebabkan kematian. Penyakit Jantung Koroner terutama menjadi penyakit yang menyebabkan kematian dibandingkan

\footnotetext{
${ }^{1}$ Korespondensi mengenai isi artikel ini dapat dilakukan melalui firma.agus.t@mail.ugm.ac.id

2 Atau melalui muhana@ugm.ac.id
}

dengan penyakit lain. WHO menaksir sebanyak 17,5 juta orang meninggal akibat penyakit jantung dan pembuluh darah pada tahun 2012 mewakili 31\% dari semua kematian. Sebanyak 7,4 juta jumlah kematian global disebabkan oleh penyakit jantung koroner dan 6,7 juta disebabkan oleh stroke (WHO, 2015).

Kematian yang disebabkan oleh penyakit jantung koroner di Indonesia 
diperkirakan akan meningkat setiap tahunnya. Kematian yang disebabkan oleh penyakit jantung dan pembuluh darah, terutama jantung koroner dan stroke diperkirakan akan terus meningkat sampai 23,3 juta kematian pada tahun 2030 (Kementerian Kesehatan RI, 2014). Berdasarkan diagnosis dokter, prevalensi penyakit jantung koroner di Indonesia tahun 2013 sebesar 0,5\% atau diperkirakan sekitar 883.447 orang, sedangkan berdasarkan diagnosis dokter/gejala sebesar $1,5 \%$ atau diperkirakan sekitar 2.650.340 orang (Kementerian Kesehatan RI, 2014).

Beberapa penelitian menjelaskan bahwa individu yang mengalami penyakit kronis seperti jantung koroner pada awalnya akan mengalami lebih banyak afek negatif dibandingkan afek positif. Menurut penelitian Harrington (2013) individu yang terkena penyakit jantung pada awalnya akan mengalami kecemasan, ketakutan akan ketidakberdayaan dan kematian. Denollet (1998) juga melaporkan tentang adanya hubungan emosi negatif dengan jantung koroner, yang meliputi kecemasan, marah, gejala depresi, kekhawatiran dan stress psikologis, kelelahan yang berlebihan dan putus asa.

Afek positif, afek negatif, dan kepuasan hidup merupakan tiga komponen pada kesejahteraan subjektif (Diener, 1984). Ketiga komponen tersebut merupakan penentu kesejahteraan subjektif seseorang. Afek positif penting dimiliki oleh pasien jantung koroner, karena bukti-bukti menunjukkan suatu hubungan antara trait afek positif dan rendahnya keadaan tidak sehat, serta afek positif dapat mengurangi gejala nyeri (Pressman dan Cohen, 2005). Apabila pasien jantung koroner memiliki afek positif yang tinggi maka kondisi fisiknya akan terhindar dari kekambuhan nyeri dada atau angina.

Kesejahteraan subjektif menjadi salah satu faktor penyebab umur panjang dan kesehatan yang baik menjadi hal yang penting akhir-akhir ini. Pressman dan Cohen (2005) menerangkan afek positif berkaitan dengan kesehatan fisik dan umur yang panjang, selain itu afek positif juga memprediksi tingkat survive seseorang terhadap penyakit yang dideritanya. Oleh karena itu, afek positif merupakan bagian dari kesejahteraan subjektif yang sangat dibutuhkan oleh pasien jantung koroner.

Masyarakat di Indonesia dikenal dengan masyarakat kolektivis dan berpegang pada nilai-nilai religius dalam kehidupannya. Penelitian mengenai religiusitas di Indonesia tidak terlepas dari konteks bahwa Indonesia dikenal sebagai negara yang menjunjung tinggi nilai religiusitas sebagai norma sosial (dalam Wahdani, 2013). Studi fenomenologis mengenai makna sakit pada penderita jantung koroner menunjukkan hasil bahwa penderita jantung koroner kembali ke agama dan meningkatkan religiusitasnya sebagai upaya untuk bisa menerima penyakitnya (Hamzah, Dewi \& Suparno, 2014).

Penelitian Ellison membuktikan bahwa variabel religiusitas menyumbang sekitar $5 \%-7 \%$ pada variansi kepuasan hidup seseorang, dan hanya menyumbang sekitar 2\%-3\% pada variansi afek seseorang. Pada penelitian tersebut juga didapatkan hasil bahwa agama tidak menghilangkan pengalaman negatif seseorang dan meningkatkan pengalaman positif dalam hidup sehingga tidak mempengaruhi kesejahteraan emosional individu.

Orang-orang yang religius tetap dapat memiliki kepuasan hidup yang tinggi meski pun mendapat ujian penyakit 
kronis seperti jantung koroner. Pasien jantung koroner yang religius memandang bahwa Tuhan memberi cobaan sebagai bentuk kasih sayang sehingga kepuasan hidupnya tidak mudah menurun. Hal tersebut diperkuat dengan penelitian yang dilakukan oleh Myers (2008) yang menemukan bahwa orang-orang yang aktif secara religius merasakan kebahagiaan yang lebih besar dan kepuasan hidup yang lebih besar daripada orang-orang yang tidak religius. Penelitian dari Peacock dan Paloma (1999) juga menemukan bahwa kedekatan dengan Tuhan merupakan salah satu prediktor dari kepuasan hidup pada semua rentang umur.

Penyakit jantung koroner merupakan salah satu bentuk penyakit kronis yang dapat berpengaruh pada kesejahteraan subjektif individu. Religiusitas sebagai variabel seperti sikap, perilaku, dan pengalaman memiliki hubungan dengan kesejahteraan subjektif (Lewis, Maltby, \& Day, 2005). Beberapa penelitian juga menunjukkan religiusitas berhubungan dengan tingginya kepuasan hidup yang merupakan salah satu komponen kesejahteraan subjektif. Hal tersebut menjadi landasan penelitian ini perlu dilakukan untuk mengetahui apakah religiusitas berkorelasi positif dengan kesejahteraan subjektif pada pasien jantung koroner.

\section{Metode}

Penelitian ini dilakukan di Rumah Sakit X di Purwokerto. Subjek pada penelitian ini adalah pasien jantung koroner di Rumah Sakit $X$ yang beragama Islam, berusia 40 80 tahun, berjenis kelamin laki-laki dan perempuan, serta masih mampu memahami serta merespon pertanyaan dengan baik.
Variabel independen dalam penelitian ini adalah religiusitas, sedangkan variabel dependen adalah kesejahteraan subjektif. Alat ukur yang digunakan yaitu Skala Kesejahteraan Subjektif dan Skala Religiusitas. Skala Kesejahteraan Subjektif menggunakan skala yang disusun oleh Utami (2008) yang terdiri dari subskala afek dan subskala kepuasan hidup berdasarkan teori Diener (1984). Subkala afek terdiri dari 27 aitem afek positif dan 29 aitem afek negatif. Sedangkan subskala kepuasan hidup terdiri dari 5 aitem.

Skala Religiusitas yang digunakan dalam penelitian merupakan Skala Religiusitas yang dimodifikasi dari Skala Religiusitas yang disusun Dewi (2008) dan beberapa aitem Skala Religiusitas pada dimensi ilmu disusun sendiri oleh peneliti. Skala Religiusitas pada penelitian ini berdasarkan pada dimensi religiusitas menurut Glock dan Stark (dalam Ancok dan Suroso, 2011) yang meliputi dimensi keyakinan, pengamalan, pengalaman, peribadatan dan dimensi ilmu. Skala Religiusitas pada penelitian ini terdiri dari Skala Religiusitas I yang berjumlah 32 aitem dan Skala Religiusitas II yang berjumlah 20 aitem.

Penelitian menggunakan metode pengumpulan data secara langsung. Peneliti membagikan kuisioner secara langsung pada pasien penyakit jantung koroner di Rumah Sakit X. Data hasil penelitian dianalisis dengan teknik analisis Product Moment dari Pearson menggunakna program SPSS 20 for Windows.

\section{Hasil}

Sebelum melakukan proses pengumpulan data, peneliti terlebih dahulu melakukan persiapan alat ukur penelitian dengan melakukan uji validitas isi Skala 
Religiusitas yang dilakukan oleh tujuh expert judgement. Nilai validitas isi Aiken's V Skala Religiusitas bergerak dari 0,50 sampai 0,96. Peneliti menetapkan batas 0,50 . Setelah proses analisis dilakukan terdapat 52 Aitem yang memenuhi standar minimal untuk uji coba dan tidak ada aitem yang gugur. Setelah melakukan uji validitas isi peneliti kemudian melakukan uji coba skala penelitian. Pengambilan data uji coba dilakukan dengan menyebar kuisioner secara langsung kepada 30 pasien jantung koroner di Rumah Sakit X. Proses uji coba skala dilaksanakan pada tanggal 7 Januari hingga 16 Januari 2017. Peneliti kemudian melakukan estimasi reliabilitas dan seleksi aitem berdasarkan daya diskriminasi aitem guna mendapatkan aitem yang gugur dan sahih sebagai alat ukur penelitian.

Setelah dilakukan uji daya diskriminasi aitem melalui teknik korelasi aitem total, terdapat tiga aitem yang gugur dari 27 aitem subskala afek positif. Daya diskriminasi aitem subskala afek positif berkisar antara 0,381 sampai dengan 0,884 . Pada subkala afek negatif terdapat dua aitem yang gugur dari 29 aitem subskala afek negatif. Daya diskriminasi aitem subskala afek negatif berkisar antara 0,429 sampai dengan 0,829. Subskala kepuasan hidup setelah dilakukan analisis daya beda aitem tidak menghasilkan aitem gugur. Daya diskriminasi aitem dari subskala kepuasan hidup berkisar antara 0,323 sampai dengan 0,643. Reliabilitas Skala Kesejahteraan Subjektif sebesar 0,946 untuk afek positif, 0,963 untuk afek negatif dan 0,671 untuk subskala kepuasan hidup setelah menggugurkan aitem yang tidak memenuhi standar minimal daya diskriminasi aitem yang baik.

Terdapat sebelas aitem yang gugur dari 32 aitem Skala Religiusitas I. Skala Religiusitas I memiliki daya diskriminasi aitem antara 0,212 sampai dengan 0,735..
Aitem dengan indeks daya beda 0,2 tetap dipertahankan agar jumlah aitem tiap dimensi berimbang. Pada Skala Religiusitas II terdapat sebelas aitem yang gugur dari 20 aitem Skala Religiusitas II. Skala Religiusitas II memiliki daya diskriminasi aitem yang berkisar antara 0,36 sampai dengan 0,76. Skala Religiusitas memiliki koefisien reliabilitas 0,903 untuk Skala Religiusitas I dan 0,715 untuk Skala Religiusitas II setelah menggugurkan aitem yang tidak memenuhi standar minimal daya diskriminasi yang baik.

Peneliti melakukan uji asumsi sebelum melakukan uji hipotesis penelitian. Uji asumsi yang dilakukan peneliti terdiri dari uji normalitas dan uji linieritas. Data pada penelitian ini terdistribusi normal setelah dilakukan uji normalitas. Data terdistribusi normal apabila nilai signifikansi K-S Z $p>0,05$. Pada penelitian ini nilai $\mathrm{p}$ pada variabel religiusitas sebesar 0,754 dan nilai $p$ pada variabel kesejahteraan subjektif sebesar 0,558. Uji linieritas dilakukan untuk mengetahui apakah variabel religiusitas dan variabel kesejahteraan subjektif memiliki hubungan yang linier atau tidak. Dua variabel yang diuji dapat dikatakan linier apabila linieritasnya $p<0,05$ dan deviasi linieritasnya $p>0,05$. Berdasarkan data yang diolah didapatkan nilai liniearity sebesar $0,004(p<0,01)$. Nilai Deviation from Linearity sebesar 0,523 $(\mathrm{p}>0,05)$. Berdasarkan hasil linierity dan Deviation from Linearity menunjukkan kedua variabel memiliki hubungan yang linier.

Berdasarkan hasil uji korelasi Product Moment diperoleh nilai r sebesar 0,417 dan nilai $p$ sebesar $0,000 \quad(p<0,01)$. Hasil tersebut menunjukkan bahwa religiusitas memiliki hubungan yang signifikan dengan kesejahteraan subjektif. Selain itu, hubungan positif antara religiusitas dan kesejahteraan subjektif menunjukkan 
bahwa semakin tinggi religiusitas individu maka semakin tinggi pula kesejahteraan subjektif individu, dan sebaliknya semakin rendah religiusitas individu maka semakin rendah pula kesejahteraan subjektif individu, sehingga dapat dinyatakan bahwa hipotesis diterima.

$$
\text { Peneliti melakukan analisis }
$$

tambahan untuk menguji perbedaan kesejahteraan subjektif pada pasien jantung koroner di Rumah Sakit X ditinjau dari jenis kelamin dan lama sakit, dengan menggunakan analisis Independent Sample T-Test. Sementara untuk melihat perbedaan kesejahteraan subjektif ditinjau dari usia dan pendidikan menggunakan analisis One Way ANOVA.

Analisis uji beda menunjukkan tidak terdapat perbedaan yang signifikan pada variabel kesejahteraan subjektif ditinjau dari jenis kelamin dengan nilai $t$ sebesar 0,70 dan nilai signifikansi sebesar 0,944 $(\mathrm{p}>0,05)$.

Analisis uji beda menunjukkan tidak terdapat perbedaan yang signifikan pada variabel kesejahteraan subjektif ditinjau dari lama sakit dengan nilai t sebesar 0,408 dan nilai signifikansi sebesar 0,685 $(p>0,05)$. Hal tersebut berarti tidak terdapat perbedaan kesejahteraan subjektif subjek penelitian dengan lama sakit 0-2 tahun dengan subjek penelitian yang lama sakit lebih dari 2 tahun.

Analisis uji beda kesejahteraan subjektif ditinjau dari usia menunjukkan tidak terdapat perbedaan yang signifikan. Nilai $F$ sebesar 0,063 dan nilai $p$ sebesar $0,979$ ( $p>0,05)$. Hal tersebut menunjukkan tidak terdapat perbedaan yang signifikan antara subjek berusia 40-49, 50-59, 60-69 dan 70-79 tahun.

Analisis uji beda menunjukkan bahwa tidak terdapat perbedaan yang signifikan pada kesejahteraan subjektif subjek penelitian ditinjau dari pendidikan terakhir dengan nilai $F$ sebesar 1,239 dan nilai signifikansi sebesar 0,303 ( $p>0,05)$. Hasil tersebut menunjukkan bahwa tidak terdapat perbedaan kesejahteraan subjektif yang signifikan antara subjek dengan tingkat pendidikan terakhir SD, SLTP, SLTA dan Perguruan Tinggi.

\section{Diskusi}

Hasil penelitian ini menunjukkan bahwa terdapat hubungan yang signifikan antara religiusitas dengan kesejahteraan subjektif yang ditunjukkan dengan nilai korelasi kedua variabel $\mathrm{r}_{\mathrm{xy}}$ sebesar 0,417 dengan taraf signifikansi sebesar 0,000 $(p<0,01)$. Hal tersebut menunjukkan bahwa korelasi antara religiusitas dengan kesejahteraan subjektif bersifat positif, yang berarti semakin tinggi nilai religiusitas pada individu, maka semakin tinggi juga kesejahteraan subjektif yang dirasakan oleh individu, begitu juga sebaliknya. Oleh karena itu, hipotesis yang diajukan oleh peneliti dapat diterima.

Temuan penelitian ini sesuai dengan pendapat Seligman (2002) yang menyatakan bahwa individu yang religius merasa lebih puas dan lebih bahagia dengan kehidupannya dibandingkan dengan individu yang tidak religius. Diener (2011) mengemukakan bahwa individu cenderung akan meningkatkan religiusitasnya ketika dihadapkan pada keadaan yang sulit. Keadaan yang sulit akan memprediksi meningkatnya religiusitas pada individu. Hubungan antara religiusitas dengan kesejahteraan subjektif menunjukan hubungan yang positif ketika terjadi peningkatan situasi negatif pada individu (Diener,2011).

Hasil penelitian ini sejalan dengan hasil penelitian di Amerika yang membuktikkan bahwa religiusitas berkorelasi secara positif dengan evaluasi hidup yang positif. Evaluasi tersebut meliputi mendapatkan pengalaman yang 
menyenangkan, sering tersenyum dan tertawa (Diener,2011). Penelitian secara meta-analisis yang membandingkan subjek Amerika-Eropa dan Eropa menunjukkan subjek dengan religiusitas yang lebih tinggi memiliki depresi yang lebih rendah (Smith, McCullough, \& Poll, 2003). Depresi yang rendah adalah salah satu tanda seseorang memiliki kesejahteraan subjektif yang baik.

Hasil penelitian ini sesuai dengan penemuan berbagai penelitian di Amerika yang menyebutkan bahwa terdapat korelasi yang signifikan antara kebahagiaan dengan keyakinan seseorang akan agamanya, kekuatan hubungan seorang dengan Tuhannya, ibadah, serta partisipasi, dalam kegiatan keagamaan (Eddington \& Shuman, 2008). Selain itu, hasil penelitian ini juga sejalan dengan penelitian Diener dan Ryan (2009) yang menunjukan bahwa terdapat hubungan yang positif antara agama dengan kesejahteraan subjektif terutama berkaitan dengan makna dan tujuan hidup manusia. Pasien jantung koroner yang memiliki religiusitas tinggi cenderung memiliki religiusitas kesejahteraan subjektif yang tinggi disebabkan mereka mencoba menemukan makna hidup melalui agama agar tetap bahagia walau hidup dengan penyakit kronis.

Kategorisasi skor subjek penelitian pada variabel kesejahteraan subjektif dibedakan menjadi tiga kategori yaitu rendah, sedang dan tinggi. Terdapat 10 orang subjek (15\%) masuk dalam kategori rendah. Subjek dengan kategori sedang sebanyak 44 orang (66\%). Sementara subjek yang termasuk kategori tinggi sebanyak 13 orang (19\%). Berdasarkan skor kategorisasi subjek pada variabel kesejahteraan subjektif, dapat dilihat bahwa mayoritas subjek penelitian memiliki kesejahteraan subjektif pada kategori sedang atau cukup tinggi. Hal tersebut menunjukan bahwa pasien jantung koroner masih dapat merasakan afek positif yang tinggi dan memiliki kepuasan hidup yang cukup baik meskipun menderita penyakit kronis.

Kategorisasi skor religiusitas subjek penelitian terbagi menjadi tiga kategori, yaitu kategori rendah, sedang dan tinggi. Terdapat delapan orang subjek penelitian $(12 \%)$ dalam kategori rendah. Subjek dalam kategori sedang berjumlah 48 orang (72\%). Sementara untuk subjek dengan kategori religiusitas tinggi berjumlah 11 orang $(16 \%)$. Hal tersebut menunjukkan bahwa sebagian besar pasien jantung dalam penelitian ini memiliki religiusitas dalam kategori sedang atau cukup tinggi.

Religiusitas menyediakan komponen fungsi yang dapat memenuhi kebutuhan manusia. Fungsi dari religiusitas salah satunya untuk meningkatkan makna dan tujuan hidup (Chamberlain \& Zika, dalam Diener, 2014). Selain itu religiusitas juga dapat meningkatkan level dukungan sosial yang lebih tinggi dan strategi koping yang positif ketika dihadapkan pada situasi kehilangan atau situasi yang sulit (Peterson \& Seligman, dalam Diener 2014). Hal tersebut menunjukkan bahwa religiusitas dapat berkontribusi pada kesejahteraan subjektif individu terutama ketika dihadapkan pada situasi yang sulit. Pasien jantung koroner menghadapi situasi yang sulit yaitu penyakit kronis yang diderita selama bertahun-tahun sehingga mereka cenderung meningkatkan religiusitasnya untuk tetap dapat merasa bahagia.

Penelitian menunjukkan bahwa seseorang yang memiliki kepercayaan tinggi terhadap agamanya mampu menerima dirinya sendiri, ditandai dengan individu tersebut mampu mengatasi masalah-masalah yang muncul seperti penyakit kronis, pengangguran dan rasa kehilangan (Gartner, Larson \& Allen 1991, 
dalam Rezi, 2012). Pasien jantung koroner merupakan individu yang menghadapi situasi yang sulit berupa penyakit kronis. Subjek penelitian yang memiliki religiusitas tinggi mampu menerima dirinya sendiri sehingga dapat mengatasi masalah yang muncul seperti penyakit kronis dan membantu mempertahankan kesehatan mental (Argyle, 2001).

Hasil penelitian ini juga sesuai dengan hasil penelitian mengenai religiusitas dan kesejahteraan subjektif di Indonesia. Berdasarkan penelitian Yuliana (2014) tentang religiusitas dengan kebahagiaan pada dewasa awal, subjek menjawab bahwa hal yang membuat hidup mereka bahagia adalah kebutuhan spiritualitas atau aktifitas religius (53\%). Penelitian mengenai religiusitas di Indonesia tidak terlepas dari konteks bahwa Indonesia dikenal sebagai negara yang menjunjung tinggi nilai religiusitas sebagai norma sosial (dalam Wahdani, 2013).

Kebahagiaan pada orang-orang Muslim di Indonesia dipengaruhi salah satunya oleh nilai-nilai agama. Hasil penelitian Yuliana (2014) menemukan terdapat hubungan positif yang signifikan antara religiusitas dengan kebahagiaan pada dewasa awal. Penelitian Ramadhan (2014) juga menemukan adanya hubungan yang positif antara religiusitas dengan kebahagiaan mahasiswa bidik misi. Hasil penelitian ini searah dengan hasil penelitian-penelitian sebelumnya di Indonesia meskipun dengan karakteristik subjek yang berbeda.

$$
\text { Beberapa hasil penelitian }
$$

membuktikan bahwa religiusitas berkontribusi pada peningkatan kepuasan hidup individu. Pada penelitian ini juga menemukan hasil yang tidak jauh berbeda mengenai kontribusi religiusitas pada kesejahteraan subjektif. Survey yang dilakukan secara konsisten menunjukkan orang-orang yang religius lebih bahagia dan lebih puas dengan kehidupannya (Argyle, 2001). Penelitian yang dilakukan oleh Kortt, Dollery, \& Grant (2014) membuktikan bahwa kehadiran dalam acara keagamaan akan berdampak pada semakin tingginya kepuasan hidup seseorang. Kepuasan hidup adalah salah satu komponen pada kesejahteraan subjektif pada pasien jantung koroner.

Berdasarkan analisis tambahan ditemukan tidak terdapat perbedaan yang signifikan pada kesejahteraan subjektif subjek penelitian ditinjau dari jenis kelamin.Hal tersebut sesuai dengan temuan penelitian Seligman yang menyatakan bahwa jenis kelamin memiliki hubungan yang tidak konsisten dengan kebahagiaan. Tingkat emosi rata-rata pria dan wanita tidak berbeda namun wanita lebih bahagia dan juga lebih sedih daripada pria (Seligman, 2005).

Uji beda yang dilakukan peneliti menunjukkan tidak terdapat perbedaan yang signifikan pada kesejahteraan subjektif pasien jantung koroner ditinjau dari usia. Hasil tersebut menunjukkan tidak adanya perbedaan kesejahteraan subjektif yang signifikan pada subjek yang berusai 40-49 tahun, 50-59 tahun, 60-69 tahun dan 70-79 tahun. Hasil pada penelitian ini tidak sesuai dengan penelitian Mroezek dan Spiro (dalam Diener \& Ryan, 2009) menemukan bahwa kepuasan hidup sebenarnya meningkat pada usia 45 sampai dengan 65 tahun dan terjadi penurunan kebahagiaan pada usiausia menjelang kematian.

Penelitian ini menunjukkan tidak adanya perbedaan yang signifikan pada kesejahteraan subjektif pasien jantung koroner ditinjau dari tingkat pendidikan terakhir. Hal tersebut tidak sesuai dengan penelitian Arku, Glen, Filson, \& Shute (2007) yang menyatakan bahwa pengetahuan seseorang tentang tujuan 
hidup, makna hidup sangat mempengaruhi kesejahteraan subjektif seseorang. Hasil penelitian ini sesuai dengan temuan penelitian Palmore (dalam Diener, 2009) bahwa pendidikan tidak begitu kuat pengaruhnya terhadap kesejahteraan subjektif.

Beberapa penelitian juga menunjukan bahwa tidak adanya hubungan antara pendidikan dengan kesejahteraan subjektif, meskipun beberapa faktor telah dikontrol (Toseland \& Rasch, dalam Diener 2009). Hasil penelitian mengenai pengaruh tingkat pendidikan dengan kesejahteraan subjektif menarik untuk dikaji lebih lanjut karena menimbulkan hasil yang berbeda-beda.

Hasil uji beda menunjukkan tidak adanya perbedaan yang signifikan pada kesejahteraan subjektif pasien jantung koroner ditinjau dari lama sakit. Tidak terdapat perbedaan kesejahteraan pada pasien yang lama sakit antara 0-2 tahun dengan pasien yang lama sakit lebih dari 2 tahun. Hal tersebut sesuai dengan pendapat Neimeyer (dalam Wardhani, 2011) yang menyatakan bahwa lama sakit seseorang tidak berpengaruh secara signifikan terhadap kecemasan yang dirasakannya. Kecemasan pasien jantung koroner karena sakit yang bertahun-tahun atau yang sakit berbulan-bulan tidak memberikan perbedaan pada kesejahteraan subjektif pasien.

Penelitian ini memiliki keterbatasan pada alat ukur penelitian yang kurang dapat mengungkap dimensi-dimensi religiusitas dalam Islam. Penelitian ini hanya melibatkan subjek-subjek yang beragama Islam namun alat ukur yang digunakan berdasarkan pada dimensi religiusitas secara umum dari Glock \& Stark. Oleh karena itu, nilai korelasi antara religiusitas dengan kesejahteraan subjektif pada penelitian ini cukup rendah disebabkan keterbatasan alat ukur religiusitas.

\section{Kesimpulan}

Hasil penelitian menunjukkan bahwa terdapat hubungan positif antara religiusitas dengan kesejahteraan subjektif pada pasien jantung koroner. Hal tersebut berarti bahwa semakin tinggi religiusitas pada diri individu maka semakin tinggi juga kesejahteraan subjektif yang dirasakan. Sebaliknya, semakin rendah religiusitas pada diri individu, maka semakin rendah juga kesejahteraan subjektifnya.

Skor kesejahteraan subjektif subjek penelitian sebagian besar berada pada tingkatan sedang. Skor religiusitas subjek penelitian juga berada pada tingkatan sedang. Hal tersebut berarti mayoritas subjek penelitian ini memiliki kesejahteraan subjektif dan religiusitas yang cukup tinggi.

\section{Saran}

Peneliti selanjutnya diharapkan dapat menggunakan alat ukur religiusitas yang dapat mengungkap dimensi-dimensi dalam agama Islam dan berdasarkan teori yang sesuai dengan agama Islam. Peneliti selanjutnya juga dapat meneliti mengenai kesejahteraan subjektif pada pasien jantung koroner di tempat penelitian yang berbeda dan beragam sehingga dapat memperkaya hasil penelitian.

\section{Kepustakaan}

Ancok, D., \& Suroso, F. N. (2011). Psikologi islami, solusi atas problem-problem psikologi Cetakan VIII. Yogyakarta: Pustaka Pelajar. 
Argyle, M. (2001).The Psychology of Happiness $2^{\text {nd }}$ Edition. East Sussex: Routledge.

Arku, F.S., Glen, C., Filson. \& Shute, J. (2007).An Empirical approach to the study of well being among rural men and women in Ghana.Rural Studies, University of Guelph, Guelph, Canada.

Denollet, J. (1998). Personality and coronary heart disease : the type-d scale- 16 (dS-16). The society of behavioral medicine, 20 (3), 209-215

Dewi, C. (2008). Hubungan antara religiusitas dengan kecemasan menghadapi kematian pada lanjut usia. (Skripsi Tidak Dipublikasikan). Fakultas Psikologi Universitas Gadjah Mada, Yogyakarta.

Diener, E. (1984). Subjective well-being. Psychological Bulletin, 95 , 542-575.

Diener, E. (2009). Assessing well-being: The Collected Works of Ed Diener. Netherlands: Springer.

Diener, E \& Ryan, Katherine. (2009). Subjective Well-being : A General Overview. South African Journal of Psychology. 39(4), 391-406.

Diener \& Chan. (2011). Happy People Live Longer: Subjective Well-Being Contributes to Health and Longevity. Journal of Applied Psychology: Health and Well Being, 3 (1), 1-43. doi:10.1111/j.17580854.2010.01045.x

Eddington, $\mathrm{N}$ \& Shuman, R. (2008).Subjective Well Being (Happiness).Continuing Psychology Education.http://www.texcpe.com/cp e/PDF/ca-happiness.pdf

Ellison, C. G. ( 1991). Religious involvement and subjective wellbeing. Journal of Health and Social Behavior, 32, 80-99.
Hamzah, I. F., Dewi, E. H., \& Suparno. (2014). Makna sakit pada penderita jantung koroner: Studi fenomenologis. Jurnal Psikologi Undip, 13 (1), 1-10

Harrington, R. (2013). Stress, health and well-being: Thriving in the 21st century. Belmont, CA: Wadsworth, Cengage Learning.

Kementrian Kesehatan RI. (2014). Situasi kesehatan jantung. Jakarta selatan: kementrian kesehatan RI

Kortt, M.A, Dollery, B., \& Grant, B (2014).Religion and life satisfaction down under. Journal of happiness studies (online).

Lewis, C., Maltby, J. \& Day, L. (2005).Religious orientation, religious coping and happiness among UK adults. Personality and Individual Differences, 38(5), 11931202. doi:10.1016/j. paid.2004.08.002

Myers, D. G. (2008).Religion and human flourishing. In M. Eid \& R. Larsen (eds.), The science of subjective wellbeing. New York: Guilford.

Peacock, JR \& Paloma MM. (1999).Religiosity and Life Satisfaction across the Life Course. Social Indicators Research, 48, 321345.

Pressman, S.D., Cohen, S. (2005). Does positive affect influence health? Psychologycal Bulletin, 131, 925-971

Ramadhan, A. F. (2014). Hubungan antara religiusitas dengan kebahagiaan pada mahasiswa bidikmisi Universitas Gadjah Mada. (Skripsi Tidak Dipublikasikan). Fakultas Psikologi Universitas Gadjah Mada, Yogyakarta.

Rezi, A. (2012). Hubungan antara Religusitas dengan Kebahagiaan Remaja. (Skripsi Tidak Dipublikasikan). Fakultas Psikologi Universitas Gadjah Mada, Yogyakarta. 
Seligman, M. E. P. (2002). Authentic happiness. New York: Free Press.

Seligman, M. E. P., Steen, T. A., Park, N., \& Peterson, C. (2005). Positive psychology progress: Empirical validation of interventions. American Psychologist, $5,410-421$

Smith, Timothy B; McCullough, Michael E \& Poll, Justin. (2003). Religiousness and Depression: Evidence for a Main Effect and the Moderating Influence of Stressful Life Events. Psychological Bulletin by the American Psychological Association, 129 (4), 614-636.

Utami, M.S. (2008). Subjective well-being pada mahasiswa. (Laporan Penelitian Tidak diterbitkan). Fakultas Psikologi Universitas Gadjah Mada, Yogyakarta.

Wahdani F, N. (2013) Pursuit of happiness for muslim: The role of religious orientation to achieve happiness. (Skripsi Tidak Diterbitkan). Fakultas Psikologi Universitas Gadjah Mada, Yogyakarta.
Wardhani, F. W. (2011). Hubungan antara religiusitas dengan kecemasan menghadapi kematian pada penyandang diabetes mellitus tipe II. (Skripsi Tidak Dipublikasikan). Fakultas Psikologi Universitas Gadjah Mada, Yogyakarta.

World Health Organization.(2015). Global health obseravatory (GHO) data.diakses dari htttp://who.int/gho/en/ pada tanggal 17 November 2016.

Yuliana, N. D. (2014). Hubungan antara religiusitas dengan kebahagiaan pada dewasa awal.(Skripsi Tidak Dipublikasikan). Fakultas Psikologi Universitas Gadjah Mada, Yogyakarta 